\title{
KRYTYCZNE SPOJRZENIE Z PERSPEKTYWY PSYCHOLOGA NA GRANICE PORADNICTWA FILOZOFICZNEGO W PORÓWNANIU DO PSYCHOTERAPII, POMOCY PSYCHOLOGICZNEJ I COACHINGU
}

\begin{abstract}
Streszczenie. Tekst ten stanowi próbę ogólnego zdefiniowania doradztwa filozoficznego, a także porównania go do profesjonalnej pomocy psychologicznej, psychoterapii i coachingu. Na początku opisana została pomoc psychologiczna z jej rodzajami i porównana do możliwych obszarów pokrewnych doradztwu filozoficznemu. Następnie opisano psychoterapię i jej poszczególne szkoły, porównując je do oddziaływań doradcy filozoficznego. Na końcu opisano coaching, nakreślając wspólne elementy z doradztwem udzielanym przez filozofa. Ogólne wnioski płynące z porównania tych różnych form pracy z ludźmi można określić następująco: Doradztwo filozoficzne jest dziedziną młodą w polskiej rzeczywistości. Koniecznym jest dookreślenie jego ram poprzez odróżnienie od pracy psychologa, psychoterapeuty i coacha. Ważną kwestią jest nacisk na wizję doradztwa filozoficznego jako metody pracy z osobami zdrowymi psychicznie. Doradztwo takie nie może być procesem zastępującym psychoterapię indywidualną lub grupową. Jest to ciekawa forma pracy, która ma duży potencjał i szansę odnalezienia się jako dziedzina rozwoju osobistego dla osób zdrowych psychicznie.
\end{abstract}

Słowa kluczowe: poradnictwo filozoficzne, coaching filozoficzny, profesjonalna pomoc psychologiczna, psychoterapia, coaching

1. Wstęp. 2. Czym jest poradnictwo filozoficzne? 3. Profesjonalna pomoc psychologiczna.

4. Formy pomocy psychologicznej. 5. Psychoterapia. 6. Coaching. 7. Podsumowanie.

\section{WSTĘP}

Pojawia się coraz więcej form profesjonalnej pracy nad sobą, własną psychiką, rozwojem osobistym. Oferty takiej pracy możemy odnaleźć w ramach psychologii, filozofii, pedagogiki, psychiatrii, psychoterapii, teologii. Początki współczesnej pracy nad samorozwojem związane są 
z psychologia jako dyscypliną wyodrębnioną z filozofii. Psychologia podlega zmianom i poza rozwojem naukowym jest także dyscypliną praktyczną. W ciągu ostatnich 60 lat zaszły znaczące zmiany w rozumieniu pomocy psychologicznej niesionej potrzebującym jej osobom. W latach 50. ubiegłego wieku w psychologii dominowało podejście dwubiegunowe: pacjent vs osoba zdrowa. Taki podział zakładał, że albo ktoś jest chory i jest pacjentem, co do którego można zastosować jakieś leczenie, albo nie podlega leczeniu, bo jest osobą zdrową. Pacjent więc kojarzy się z osobą chorą, biernie oczekującą na leczenie ${ }^{1}$. Takie podejście jest formą odebrania podmiotowości osobie pragnącej otrzymać jakąś formę pomocy. W późniejszym okresie zauważono, że podejście to można zmienić niejako przywracając podmiotowość pacjentom poprzez nadanie im miana klientów. Pojęcie klienta wprowadzono w celu podkreślenia decyzyjności osoby, która ma wpływ na udzielaną sobie pomoc. W ramach tego podejścia pomoc innym osobom w ich trudnościach / rozwoju otworzyła się na nowe możliwości. Poza pomocą psychologiczną i psychoterapią pojawił się coaching, a swój renesans przeżywa doradztwo filozoficzne. Artykuł będzie skupiał się na porównaniu tradycyjnych form pracy z klientem / pacjentem (psychoterapia, pomoc psychologiczna) z nowszymi (coaching, poradnictwo filozoficzne).

O ile pomoc psychologiczna, psychoterapia i coaching mają ugruntowaną pozycję, o tyle poradnictwo filozoficzne w Polsce jest nową dziedziną pomocy. Trudno też o formalnie określone ramy tego, czym jest poradnictwo filozoficzne w Polsce. Poradnictwo filozoficzne jest $\mathrm{w}$ miarę nową dziedziną prężnie rozwijającą się do tej pory w USA, w Polsce spotykamy ten termin od niedawna. Nie ma jednak pomimo tego formalnie określonych granic zawodu "doradcy filozoficznego”. Co więcej granice pracy doradcy filozoficznego mogą nakładać się na inne, lepiej dookreślone formy profesjonalnej pomocy. Artykuł ten będzie próbą określenia granic i relacji pomiędzy wymienionymi

1 R.C. Carson i in., Psychologia zaburzeń, tłum. z ang. W. Dietrich i in., Gdańsk 2003. 
$\mathrm{w}$ tytule formami pracy $\mathrm{z}$ ludźmi. Przedstawione zostaną również wątpliwości, które mogą towarzyszyć pracy doradcy filozoficznego. Wątpliwości te zostaną wyrażone z perspektywy doświadczeń na polu pomocy psychologicznej, psychoterapeutycznej i coachingu.

\section{CZYM JEST PORADNICTWO FILOZOFICZNE?}

Filozofia jeszcze przed Sokratesem była dziedziną praktyczną a uprawiający ją widzieli w niej formę pomocy ludziom w ich myśleniu o swoich problemach ${ }^{2}$. Nie jest więc prawdą, że myślenie o wykorzystaniu filozofii jako metody pomocy jest nowe. Nowy jest natomiast zawód filozofa-doradcy, który przy użyciu pewnych metod pomagałby ludziom w przemyśleniu ważnych dla nich kwestii.

Wielu znakomitych terapeutów, psychologów korzystało z klasycznych dzieł filozoficznych, budując poszczególne szkoły psychoterapii. Niestety, filozofia przez lata stała się dziedziną czysto akademicką, tracąc swoją praktyczną stronę aż do 1980 roku. Pewnym przełomem i rozpoczęciem ruchu poradnictwa filozoficznego stał się fakt otwarcia przez Gerda Achenbacha praktyki filozoficznej Gesellschaft für Philosophische Praxis niedaleko Kolonii w Niemczech ${ }^{3}$. Najstarszą współczesną organizacją skupiającą filozofów praktyków jest German Society for Philosophical Practice and Counseling, założona przez Achenbacha w 1982 roku. Organizacja zaczęła rozszerzać swoją działalność i obecnie obejmuje około 16 krajów. Istnieją na świecie inne organizacje skupiające filozofów praktyków (The National Philosophical Counseling Association, American Philosophical Practitioners Association, International Society for Philosophical Practice). Poradnictwo filozoficzne wydaje się więc być na drodze do formowania się jako profesji wraz z organizacjami certyfikującymi swoich członków.

2 S. Knapp, A.C. Tjeltveit, A Review and Critical Analysis of Philosophical Counseling, Professional Psychology: Research and Practice 36(2005)5, 558.

3 http://www.achenbach-pp.de/de/termine.asp [dostęp: 28.02.2018]. 
Dokładnego przeglądu definicji poradnictwa filozoficznego dokonuje Louw kwitując swoją analizę wnioskiem, że wybranie jednej definicji, która obejmowałaby wszystkie nurty pracy w ramach poradnictwa, jest niemożliwe ${ }^{4}$, niemniej jednak autor ten zauważa pewne ważne dla poradnictwa kwestie. Pierwsza: to różni klienci wymuszają zmianę obszaru pracy, definiowania roli doradcy, zakresu obowiązków. Praca doradcy filozoficznego możliwa bowiem jest z pojedynczą osobą, parą, grupą osób, organizacją. Nie oznacza to jednak że nie jest możliwym zbudowanie ogólnej definicji doradztwa filozoficznego. Bardzo ogólna i uniwersalna definicja takiego doradztwa zawiera się w następującym zdaniu: doradztwo filozoficzne prowadzone jest przez wyszkolonego filozofa, który pomaga osobie radzić sobie ze swoim problemem ${ }^{5}$. Ta definicja zakłada, że mamy do czynienia z wyszkolonym filozofem, choć nie precyzuje, na czym szkolenie to polega i jakie wykształcenie byłoby wymagane od takiego doradcy.

Doprecyzowując tę dość ogólną definicję, można by przyjąć, że to wyszkolony (profesjonalny) filozof pomaga jednostce, choć również może pomagać grupie osób lub organizacji w radzeniu sobie $\mathrm{z}$ ich problemami. Nie pojawia się $\mathrm{w}$ tej definicji określenie według jakich metod czy zasad to się odbywa. Jeśli przyjąć, że niemożliwym jest zunifikowanie metod, to zakładamy, że każdy doradca filozoficzny będzie używał metod zgodnych z jego podejściem lub reprezentowaną szkołą filozofii. Trzecią kwestią jest to, jaki jest charakter problemów jednostki. Moim zdaniem powinniśmy mówić o doradztwie jednostce bez przeciwskazań psychologicznych, psychiatrycznych do procesu prowadzenia coachingu $\mathrm{i}$ ten argument rozwinę $\mathrm{w}$ dalszej części tekstu.

Możliwym, choć trudnym zagadnieniem jest wyznaczenie jednego lub kilku głównych paradygmatów pracy z klientem. Zgodnie

4 D. Louw, Defining Philosophical Counselling: An Overview, South African Journal of Philosophy 32(2013)1, 60-70.

5 Tamże. 
$\mathrm{z}$ wiedzą autora artykułu nie ma jednak takich opracowań porządkujących pracę filozofa jako doradcy. Również ze względu na zróżnicowanie potrzeb klientów trudno jest zbudować jeden schemat postępowania doradcy filozoficznego. Liczba szkół / podejść w filozofii może jednocześnie sprawiać, że stosowanie jednej procedury i jednego rozumienia problemu klienta nie będzie możliwe. Wprowadzenie swego rodzaju taksonomii podejść w doradztwie może mieć rolę porządkującą. Klient, który chciałby pracować z doradcą nad sensem własnego życia, wybierze wtedy paradygmat dopasowany do jego oczekiwań. Drugim plusem takiego usystematyzowania podejść może być większa świadomość klientów co do tego, w jaki sposób doradca filozoficzny może im być pomocny.

W Polsce w chwili pisania artykułu nie ma żadnego zrzeszenia doradców filozoficznych, akredytującego i oceniającej pracę takich praktyków. Powstaje więc podstawowe pytanie: kto może zostać doradcą filozoficznym w Polsce? Wydaje się, że skoro nie ma ram zawodu nakreślonych przez ustawę, każdy „samozwańczo” może zostać takim doradcą. Jeżeli nie pojawi się jakikolwiek sposób oceny kompetencji formalnych doradcy, jedynie wolny rynek może zweryfikować jakość świadczonych usług przez tę osobę. Stwarza to oczywiście zagrożenie świadczenia takich usług przez osoby niekompetentne. Problem wykonywania zawodów przez osoby bez odpowiedniego wykształcenia, wiedzy i wymaganych kompetencji dotyczy także psychologii, psychoterapii i coachingu. Jasne określenie i system certyfikacji wydają się być na razie jedyną możliwością ograniczenia działania osobom niekompetentnym.

Niezwykle ważnym pytaniem, poza definicją, jest to, jaki jest zakres kompetencji doradcy filozoficznego? Nie jest to nowy problem w literaturze międzynarodowej ${ }^{6}$. Poradnictwo filozoficzne znajduje się w obszarze takich dziedzin, jak psychologia, psychoterapia,

6 B. Šulavíková, Questions for philosophical counselling, Human Affairs 22(2012)2, 131-141; D. Louw, art. cyt. 
coaching a nawet poradnictwo kapłańskie. Zasadnym jest więc nakreślenie granic kompetencji doradców filozoficznych. Obecnie wyróżnić można dwa podejścia do poradnictwa filozoficznego. Podejście dość kontrowersyjne zakłada, że poradnictwo filozoficzne może być formą zamienną z terapią / pomocą psychologiczną dla osób zdrowych i chorych psychicznie ${ }^{7}$. Według tego podejścia kompetencje psychologa / psychoterapeuty przenikają się i nie ma między nimi granic. Takie pozbawienie granic poradnictwa filozoficznego uważam za potencjalnie szkodzące zarówno klientowi, jak i samemu doradcy filozoficznemu.

Drugie podejście ogranicza pracę doradcy filozoficznego tylko do pracy z osobami zdrowymi psychicznie (niecierpiącymi na żadne zaburzenia psychiczne i zaburzenia zachowania $\mathrm{w}$ chwili podjęcia pracy z doradcą). Doradca nie wchodzi w pole działania psychologów lub psychoterapeutów leczących choroby psychiczne, zaburzenia, pomagających w kryzysach życiowych. Raczej poradnictwo dokonywane przez kompetentnego filozofa uzupełnia fachową pomoc $\mathrm{w}$ tej dziedzinie, ale nie stanowi dla niej alternatywy. W dalszych podrozdziałach opisana zostanie problematyka doradztwa filozoficznego przez pryzmat lepiej znanych zawodów takich jak psycholog, psychoterapeuta, coach.

\section{PROFESJONALNA POMOC PSYCHOLOGICZNA}

Pomoc psychologiczna jest szerokim terminem obejmującym wiele działań, jakie psycholog może podjąć w celu udzielenia pomocy drugiej osobie. „Pomaganie jest zachowaniem prospołecznym, to jest zachowaniem nastawionym na dobro innych osób, grup, instytucji”"

7 B. Šulavíková, art. cyt.; D. Louw, art. cyt.

8 J. Czabała, H. Sęk, Pomoc psychologiczna, w: Psychologia. Podręcznik akademicki, red. J. Strelau, Gdańsk 2000; E. Aronson i in., Psychologia społeczna: serce i umysł, tłum. z ang. A. Bezwińska i in., Poznań 1997. 
Poprzez odwołanie się do pomocy różnym beneficjentom pole pomocy jest rozszerzone do potencjalnie wielu rodzajów działań. Jednocześnie ogromne znaczenie $\mathrm{w}$ tym rodzaju pracy $\mathrm{z}$ klientem ma osoba udzielająca pomocy. Ze względu na duże znaczenie i konsekwencje pomocy drugiemu człowiekowi specjalista udzielający pomocy psychologicznej powinien charakteryzować się określonymi cechami. Pomocy psychologicznej nie udziela każdy, gdyż, po pierwsze, może zaszkodzić osobom, z którymi podejmuje pracę, po drugie - sobie samemu. Tego rodzaju forma pracy powinna więc zostać w jakiś sposób zarezerwowana dla osób o specjalnych kompetencjach (np. wiedzy specjalistycznej o zaburzeniach psychicznych, umiejętności prowadzenia rozmowy). W Polsce wykonywanie zawodu psychologa reguluje ustawa o zawodzie psychologa, która jest ustawą „zawieszoną", bez odpowiednich przepisów wykonawczych ${ }^{9}$. Naukowe opracowania są dość zgodne co do zakresu kompetencji wymaganych od psychologa. W Polsce psychologiem zostaje osoba, która ukończyła studia magisterskie i otrzymała tytuł zawodowy magistra psychologii. Tytuł zawodowy uprawnia psychologa do posługiwania się specjalnymi narzędziami psychologicznymi, prowadzenia pomocy psychologicznej oraz do wydawania specjalnych opinii. Możliwe do podejmowania przez psychologa działania zawierają się w pewnych formach pomocy udzielanej klientom lub chorym pacjentom.

Tak duża dbałość środowiska psychologicznego o ograniczenie dostępu do świadczenia pomocy psychologicznej wynika poniekąd z możliwych konsekwencji udzielenia pomocy przez osobę niekompetentną. W przypadku niewłaściwej pomocy psychologicznej konsekwencją może być choroba psychiczna, śmierć, a w najlepszym razie zaniechanie chęci szukania fachowej pomocy przez klienta. Środowisko psychologiczne jest raczej zgodne co do tego, że nawet nie każdy psycholog posiadający tytuł magistra powinien pracować

9 Polskie Towarzystwo Psychologiczne, Projekt ustawy z kwietnia 1996 roku o zawodzie psychologa i samorządzie zawodowym psychologów, Warszawa 1996. 
klinicznie $\mathrm{z}$ klientem. Zdaniem autora tekstu, kryteriami utrudniającymi dyplomowanemu psychologowi udzielenie pomocy, a czasem uniemożliwiającymi ją, mogą być: 1) pokrewieństwo z klientem, 2) własna choroba psychiczna, 3) własny kryzys wpływający na pracę osoby udzielającej pomocy, 4) nietyczne podejście do zawodu, 5) brak superwizji (choćby koleżeńskiej), 6) brak praktyki klinicznej, 7) zaniechanie rozwoju własnego.

Obszar poradnictwa psychologicznego powinien być zarezerwowany dla psychologów, ale wyjątkiem są obszary, gdzie poradnictwo filozoficzne może być rozwinięciem i uzupełnieniem (nie zaprzeczeniem lub zamiennikiem) już uzyskanej pomocy psychologicznej.

\section{FORMY POMOCY PSYCHOLOGICZNEJ}

Omówiony zostanie teraz podział na sześć form oddziaływań psychologicznych wraz z możliwymi odniesieniami do poradnictwa udzielanego przez filozofa. Różne formy oddziaływań psychologicznych obejmują: 1) rozwój jednostki - wspieranie samorealizacji; 2) promocja zdrowia; 3) prewencja; 4) poradnictwo psychologiczne jako pomoc w rozwiązywaniu kryzysów; 5) interwencja kryzysowa; 6) pomoc w zmniejszeniu i usunięciu zaburzeń (psychoterapia, rehabilitacja, resocjalizacja) ${ }^{10}$. W kolejnej części tekstu omówione zostaną najważniejsze formy pomocy psychologicznej i ich relacja do poradnictwa filozoficznego.

Samorealizacja jest, zdaniem Obuchowskiego, poszukiwaniem sensu życia ${ }^{11}$. Sens życia jest procesem, w którym ludzie kompensują swoje braki, uzyskują wyższy poziom funkcjonowania, przetwarzają wady w zalety, zło w dobro, słabość w siłę ${ }^{12}$. Wspomaganie

10 J. Czabała, H. Sęk, art. cyt.

11 K. Obuchowski, Człowiek intencjonalny, czyli o tym, jak być sobą, Dom Wydawniczy Rebis 2000, 254.

12 A. Adler, Sens życia, tłum. z niem. M. Kreczowska, Warszawa 1986. 
samorealizacji jest procesem towarzyszenia jednostce w nadawaniu sensu własnemu życiu. Jest więc to proces, w którym psycholog (czy też osoba udzielającą pomocy psychologicznej, np. psychoterapeuta) wspomaga poprzez odpowiednie techniki pracy samorozwój klienta. Wspomaganie samorealizacji nie oznacza przy tym, że osoba udzielająca pomocy wpływa na to, jaki sens życia nada klientowi. Jest to raczej proces tworzenia możliwości, aby klient odnalazł własne odpowiedzi na pytanie o sens życia. Wspomaganie samorealizacji nie jest zarezerwowane jedynie dla psychologa, ale także dla pedagogów, psychoterapeutów, coachów i innych osób mogących bardziej lub mniej profesjonalnie wspomóc innego człowieka. Wspomaganie rozwoju osobistego zakłada przede wszystkim to, że pracujemy z osobą zdrową, w stabilnym stanie psychicznym, która potrzebuje pewnego bodźca do rozwoju. Tym bodźcem może być praca z psychologiem, coachem, ale także z doradcą filozoficznym. Doradztwo filozoficzne zajmując się szeroko rozumianym rozwojem osobistym, może używać własnych narzędzi, np. tekstów filozoficznych bardziej lub mniej klasycznych.

Promocja zdrowia nie jest rozumiana jako tylko zapobieganie występowania chorób psychicznych. Szerszą i trafniejszą definicją jest ujęcie w nurcie psychologii pozytywnej zdrowia jako umiejętności osiągnięcia przez człowieka pełni możliwości fizycznych, psychicznych i społecznych ${ }^{13}$. Definicja promocji zdrowia autorstwa Czabały i Sęk obejmuje zespół działań profesjonalnych psychologów, których celem jest kształtowanie i utrwalanie zachowań potrzebnych do rozwoju i utrzymania zdrowia jednostki ${ }^{14}$. Wydaje się oczywistym, iż również ta dziedzina pomocy psychologicznej nie może być zarezerwowana jedynie dla psychologów z wyłączeniem innych zawodów medycznych. Doradcy filozoficzni pracując z klientami nad obszarami związanymi ze zdrowiem psychicznym i fizycznym

13 Z. Słońska, Ewolucja modeli edukacji zdrowotnej, Kultura Fizyczna (1994)5-6, 16-21.

14 J. Czabała, H. Sęk, art. cyt. 
poprzez promowanie np. zdrowego stylu życia mogą w pewnym sensie spełniać podobna rolę do psychologa, który pracuje z klientem krótkoterminowo, interwencyjnie. W tym przypadku obszary pracy doradcy filozoficznego i psychologa pokrywają się częściowo.

Inną formą psychologicznej pomocy jest zapobieganie psychopatologii. Upraszczając, prewencję psychopatologii możemy określić jako działanie zapobiegające czynnikom ryzyka i wspierające zasoby jednostki w celu zapobiegania ujawnieniu się choroby psychicznej. Istnieje wiele podejść do prewencji w psychologii, wyczerpująco opisujących ten zakres działań, który podejmuje psycholog w celu przeciwdziałania czynnikom ryzyka i wspierania zasobów jednostki ${ }^{15}$. Jest to także obszar, w którym filozof jako doradca może pracować z klientem. Przejawem tego może być choćby praca nad poszukiwaniem przez ludzi sensu życia. Filozof i psycholog poprzez rozmowę o możliwych podejściach do nadania swojemu życiu sensu moga przeciwdziałać wystąpieniu czynników zagrażających jednostce, np. nadmiernemu stresowi.

Interwencja kryzysowa jest działaniem podejmowanym przez psychologa w obliczu wystąpienia jakiegoś kryzysu. Celem interwencji jest rozwiązanie najbardziej naglących problemów po wystąpieniu jakiegoś silnego stresogennego czynnika. Celem pracy po takim wydarzeniu jest intensywna pomoc w ciągu 1-12 tygodni po wystąpieniu zdarzenia traumatycznego, skoncentrowana na wypracowaniu nowych, efektywnych strategii radzenia (cooping) sobie przez klienta $^{16}$. Ten obszar ze względu na fachową pomoc udzielaną osobie w kryzysie powinien być zarezerwowany dla fachowych służb, przeszkolonych w procedurach psychologicznych. Interwencja kryzysowa

15 G.W. Albee, Prologue: A model for classifying prevention programs, Readings in Primary Prevention of Psychopathology: Basic Concepts (1984), 228-245; J. Czabała, H. Sęk, art. cyt.; A. Antonovsky, The salutogenic model as a theory to guide health promotion, Health Promotion International 11(1996)1, 11-18; G. E. Caplan, Prevention of mental disorders in children: Initial exploration, New York 1961.

16 A.R. Roberts, An overview of crisis theory and crisis intervention, New York 2000. 
obejmuje często pomoc ofiarom przemocy, ofiarom klęsk żywiołowych i wymagane jest tu wdrożenie raczej procedur oddziaływania i edukowaniu o specjalistycznej pomocy. W obszarze interwencyjnym działanie interwenta kryzysowego jest obarczone również dużą odpowiedzialnością i wymaga nieraz rozległej wiedzy klinicznej w celu rozpoznawania symptomów zaburzeń psychicznych i ewentualnego ich zapobiegania. Psycholog w obszarze interwencji kryzysowej ma czasem prawo lub nawet obowiązek działać bez zgody klienta, np. zgłaszając fakt wystąpienia przemocy domowej. Czy doradca filozoficzny jest gotowy i ma uprawnienia, aby dyrektywnie podejmować interwencję $\mathrm{w}$ takim obszarze? Nie, i choćby $\mathrm{z}$ tego powodu nie powinien zostać włączony w tego typu działania, chyba że wchodzi w skład zespołu interdyscyplinarnego.

Poradnictwo udzielane przez psychologa to forma udzielania doraźnej, krótkoterminowej pomocy osobie będącej w kryzysie. Jest to forma pomocy psychologa przeznaczona dla osób zdrowych, przeżywających kryzysy rozwojowe i trudności przystosowawcze ${ }^{17}$. Psycholog, odnosząc się do indywidualnych problemów, na podstawie swojej wiedzy fachowej doradza klientowi, w jaki sposób może on poradzić sobie z kryzysem życiowym, w którym się znajduje. Osoby zgłaszające się do psychologa nie zawsze są chorymi psychicznie w sensie zaburzenia. Nie zawsze więc wymagają leczenia psychiatrycznego. Są w stanie podjąć świadomą decyzję co do tego, na ile chcą wykorzystać radę specjalisty. Jest to obszar pomocy psychologicznej, w którą filozof nie powinien wkraczać. Poradnictwo filozoficzne powinno zostać wyraźnie odróżnione od psychologicznego. Moment kryzysu życiowego, w którym do psychologa i filozofa przychodzi klient, mogą być podobne. Jednak porada ta będzie dwoma różnymi procesami pracy z klientem. Praca doradcy filozoficznego nie będzie bowiem poprzedzona specjalistyczną diagnozą według odpowiednich kryteriów diagnostycznych. Będzie raczej wykorzystaniem pewnego

17 J. Czabała, H. Sęk, art. cyt. 
podejścia do pracy z kryzysem. Poradnictwo filozoficzne zawiera jednak element diagnozy i ewentualnego przekierowania osoby do odpowiedniej placówki, np. poradni zdrowia psychicznego.

Podsumowując, filozof może w wielu obszarach uzupełnić działania psychologa, po uzyskaniu przez osobę, która wykazuje symptomy „zaburzeń psychicznych i zaburzeń zachowania”18 (termin zaczerpnięty z nazwy kryteriów diagnostycznych ICD-10) odpowiedniej pomocy fachowej. Inną sytuacją jest praca z osobą zdrową nad obszarem samorozwoju lub zwiększania świadomości, np. w obszarze zdrowia. Tutaj prawdopodobnie to sami klienci rozstrzygną, z kim pracuje im się lepiej. Inną kwestią jest to, na ile sami klienci wiedzą, że są zdrowi lub chorzy i na ile filozof będzie wiedział, kiedy odesłać klienta do psychologa lub psychiatry w sytuacji choroby klienta. W tak niejasnych przypadkach pojawia się pytanie o granicę i etyczność pracy z osobami chorymi psychicznie.

\section{PSYCHOTERAPIA}

Psychoterapia jest definiowana jako proces dochodzenia pacjenta do zdrowia ${ }^{19}$. Psychoterapia nie jest formą oddziaływań opartą na jednej koncepcji teoretycznej. Wyróżniamy wiele podejść w psychoterapii, choć do głównych możemy zaliczyćco: 1) dynamiczne (psychoanaliza, neopsychoanaliza itp.); 2) poznawczo-behawioralne (terapia behawioralna, behawioralno-poznawcza, racjonalna, emotytywna); 3) fenomenologiczno-antropologiczne (humanistyczna, gestalt); 4) systemowo-interakcyjna (komunikacyjna, strukturalna). Inne podejścia to np. integracyjne, krótkoterminowe, skoncentrowane na rozwiązaniu. Poszczególne podejścia w psychoterapii różnią się

18 ICD-10: International statistical classification of diseases and related health problem, World Health Organization, Geneva 2011.

19 J. Czabała, Czynniki leczące w psychoterapii, Warszawa 2006.

20 H. Sek, Spoleczna psychologia kliniczna, Warszawa 1991. 
zasadniczo co do różnych płaszczyzn. Wyczerpującego opisu różnic w podejściach psychoterapeutycznych dokonał $\mathrm{Czabała}^{21}$. Na potrzeby niniejszego tekstu pokrótce opisane zostaną główne podejścia.

Psychoterapia psychoanalityczna to proces analizowania procesów umysłowych niedostępnych świadomie (uzyskiwanie wglądu) w celu leczenia zaburzeń psychicznych ${ }^{22}$.

W podejściu behawioralnym przedmiotem zainteresowania psychoterapeutów jest - dające się zaobserwować - zachowanie jednostki. Terapia ukierunkowana jest na leczenie symptomów chorobowych za pomocą uzasadnionych eksperymentalnie technik, które opierają się na podstawowych prawach uczenia się, takich jak modelowanie, wzmocnienia pozytywne, bodźcowanie awersyjne ${ }^{23}$.

W terapii poznawczej, mówiąc o etiologii zaburzeń, podkreśla się znaczenie przebiegu procesów poznawczych, zaś psychoterapia ukierunkowana jest przede wszystkim na przekształcenie treści myślenia, w następstwie czego dochodzi także do modyfikacji zachowań i uczuć z nimi skojarzonych. Obie formy terapii, tj. behawioralna i poznawcza, mają charakter dyrektywny i krótkoterminowy ${ }^{24}$.

Terapia w podejściu systemowym ma charakter dyrektywny stosowane są nakazy, rady, przepisy psychoterapeuty. Jest krótkoterminowa, ukierunkowana na rozwiązanie aktualnie zgłaszanego problemu. Jej celem jest zmiana systemu, a nie zmiana człowieka określanego mianem „zaburzonego”25. Klientem w tej terapii może być jeden człowiek, para małżeńska lub rodzina. Sama technika pracy i formy pracy mogą wtedy ulec dużej zmianie. Główna myśl,

21 J. Czabała, dz. cyt.

22 A. Freud, The ego and the mechanisms of defence, London 1992.

23 L. Grzesiuk, Psychoterapia teoria, cz. 1, Warszawa 2005.

24 Tamże. Por. A.T. Beck, J. Chodkiewicz, J. Witkowska, Terapia poznawcza uzależnień, Kraków 2007.

25 L. Grzesiuk, dz. cyt.; V. Satir, Conjoint family therapy, Palo Alto 1983; P. Minuchin, Families and individual development: Provocations from the field of family therapy, Child Development 56(1985), 289-302; M. Radochoński, Psychoterapia rodzinna w ujęciu systemowym, Warszawa 1984. 
pomimo różnych form pracy, nie ulega jednak zmianie: przyczyną i lekarstwem w chorobie może być system rodzinny.

W nurcie humanistyczno-egzystencjalnym zaburzenia są deficytami rozwoju osobowości, spowodowanymi barierami w zaspokojeniu potrzeb psychologicznych: miłości, akceptacji, autonomii, realizacji znaczących indywidualnie wartości ${ }^{26}$. Celem podjętej terapii w tym nurcie jest przeżycie korektywnych doświadczeń emocjonalnych oraz pobudzenie do refleksji nad ważnymi wartościami i wyborami życiowymi ${ }^{27}$. Intensywna praca nad przeszłością pacjenta nie jest tu głównym przedmiotem sesji terapeutycznych.

Podsumowując, w różnych nurtach psychoterapii celem jest udzielenie pomocy pacjentowi lub klientowi w mniej lub bardziej dyrektywnej formie. Teoretyczne podłoże terapeuty (rozumienie i definiowanie procesów psychicznych klienta) zmienia jego sposób pracy choć, jeśli chodzi o skuteczność takiej pracy, to generalnie wszystkie ze szkół profesjonalnej psychoterapii są skuteczne a zdaniem większości autorów raczej żadna ze szkół nie jest bardziej skuteczna ${ }^{28}$. Ważną dla wszystkich szkół psychoterapii jest jednak osoba psychoterapeuty, który jest profesjonalistą i w zależności od danego kraju ma odpowiednie uprawnienia do udzielania pomocy psychoterapeutycznej. Szkoły psychoterapii mają własny system standardów prowadzenia psychoterapii, ścieżki certyfikacji, doszkalania i superwizji jako formy nadzoru i rozwoju dla psychoterapeutów. Również $\mathrm{w}$ psychoterapii omawiany jest problem ograniczenia dostępu do pełnienia zawodu osobom nieodpowiednim. Czynnikami wyłączającymi z możliwości bycia psychoterapeutą są zdaniem de Barbaro ${ }^{29}$ : 1) brak zdolności empatii wobec klienta / pacjenta; 2) niekierowanie

26 L. Grzesiuk, dz. cyt.; L. Grzesiuk, B. Tryjarska, Jak pomagać sobie, rodzinie i innym, Warszawa 1995.

27 C.R. Rogers, The process equation of psychotherapy, American Journal of Psychotherapy 15(1961), 27-45.

28 J. Czabała, dz. cyt.

29 B. de Barbaro, Tezy o psychoterapii w Polsce, Psychoterapia 1(2013), 5-14. 
się troską o klienta / pacjenta; 3) zaburzenia lub emocjonalna niedojrzałość uniemożliwiająca prowadzenie spotkań terapeutycznych; 4) skłonność do korupcji; 5) skłonność do fanatycznego i dogmatycznego patrzenia na rzeczywistość; 6) skłonność do mechanistycznego rozumienia rzeczywistości.

Wydaje się, że doradca filozoficzny podejmując pracę z klientem, staje znowu przed pytaniem o diagnozę tej osoby. Jeśli klientem jest osoba zdrowa psychicznie, nie będąca w kryzysie, proces prowadzony przez filozofa będzie zapewne ciekawym doświadczeniem rozwojowym dla klienta. Problem pojawia się jednak przy pracy z osobami z diagnozą zaburzenia psychicznego lub zaburzenia zachowania. Osoby takie pracujące $\mathrm{z}$ filozofem, zamiast psychoterapeuta lub z psychologiem, mogą nie uzyskać w porę odpowiedniej pomocy i np. popełnić samobójstwo. Jest to najbardziej drastyczny przykład, choć nie jest odrealniony. Do doradcy filozoficznego zapewne trafią również osoby, które przerwały terapię własną lub jeszcze jej nie podjęły, mimo różnych problemów natury psychicznej. Psychoterapeuci, bez względu na szkołę, są szkoleni w radzeniu sobie z takimi sytuacjami. Mają również możliwość korzystania z tzw. superwizji, terapii własnej lub samorozwoju wspierającego ich pracę zawodową. Doradcy filozoficzni w swojej pracy nie powinni zostać pozostawieni bez wsparcia, które może być skonstruowane na kształt superwizji. $Z$ takiego rodzaju wsparcia korzystają psycholodzy, psychoterapeuci oraz także osoby będące coachami.

Poza przypadkami, gdzie rozpatrujemy pracę z filozofem zamiast z psychoterapeutą, pozostaje kwestia pracy równoległej. Praca z filozofem w formie równoległej i niekonsultowanej z psychoterapeutą wydaje się zjawiskiem raczej szkodzącym klientowi niż pomagającym. W psychoterapii przyjęło się, że pacjent pracuje z jednym psychoterapeutą, chyba że jest to program uzgodniony przez specjalistów i zaplanowany, jak np. terapia par, gdzie każdy małżonek dodatkowo ma zewnętrznych terapeutów indywidualnych. Klienci nie muszą mieć jasności co do takiej zasady, psychoterapeuci już tak. Jednym 
z podstawowych czynników leczących w psychoterapii jest relacja $\mathrm{z}$ terapeutą, budowanie zaś dwóch osobnych relacji terapeutycznych nie jest wskazane ${ }^{30}$. Pytanie, na ile dobrym rozwiązaniem mogłaby być konsultacja filozoficzna w takich przypadkach, wbudowana niejako w proces terapii, pozostaje otwarte.

\section{COACHING}

Coaching to dziedzina najnowsza z powyżej opisywanych w Polsce, o czym poniekąd może świadczyć choćby niespolszczona nazwa. Dokładne tlumaczenie terminu coach nie jest terminem brzmiącym polsko, jednak jest oficjalnie przyjętym do określenia osoby wspierającej rozwój osobisty swoich klientów. Coaching opisuje zazwyczaj pracę grupową lub indywidualną z klientami w celu wspierania rozwoju. Nie ma jednej spójnej definicji coachingu, możemy jednak odnaleźć w literaturze fachowej wiele zdefiniowania tego pojęcia. Przeglądu definicji coachingu dokonał w polskiej literaturze na przykład Łukasz Marciniak ${ }^{31}$.

Warto przyjrzeć się przykładowym definicjom coachingu. Jedna z definicji mówi o coachingu jako odblokowaniu potencjału osoby w celu maksymalizacji jej czy jego dokonań i działań ${ }^{32}$. Inna definicja opisuje coaching, jako „fascynującą dziedzinę, umożliwiającą świadczenie specjalistycznych usług, których efektem ma być umożliwienie klientowi odkrywania, aktualizowania, rozwijania i jak najpełniejszego korzystania $\mathrm{z}$ własnego potencjału”33.

30 I.D. Yalom, Existential psychotherapy, New York 1980; I.D. Yalom, M. Leszcz, R. Andruszko, Psychoterapia grupowa: teoria i praktyka, Kraków 2006; I.D. Yalom, A. Tanalska-Dulęba, Psychoterapia egzystencjalna, Warszawa 2008.

31 Ł. Marciniak, Pojęcie i odmiany coachingu, w: Coaching. Teoria, praktyka, studia przypadków, red. M. Sidor-Rządkowska, Kraków 2009, 32-36.

32 J. Whitmore, Coaching for performance: growing human potential and purpose: the principles and practice of coaching and leadership, London 2010.

33 L.D. Czarkowska, Profesjonalizm i proces profesjonalizacji w coachingu, Coaching Review 1(2010), 1-17. 
Pomimo różnych podejść coaching powinien być pracą z klientem zdrowym psychicznie. Coach nie posiada w Polsce żadnych uprawnień do pracy z osobami chorymi psychicznie i jest raczej osobą wspierającą rozwój osobisty, grupowy lub organizacyjny. Nie prowadzi jednak terapii ani pracy z osobami z problemami psychicznymi, które nie zakończyły procesu własnej psychoterapii. Można powiedzieć, że granice pomiędzy pomocą psychologiczną i psychoterapią zacierają się nieraz, pomimo dobrego ich zdefiniowania. W przypadku coachingu główne organizacje wyznaczają dość konkretne granice pracy swoich członków (International Coach Federation, International Coaching Community, Association for Coaching Association for Professional Executive Coaching and Supervision European Mentoring and Coaching Council). Co więcej: przynależność coacha do którejś z federacji umożliwia unifikację pracy coacha, wytyczenie kodeksu etycznego, według którego klient pracuje ze specjalistą. Część organizacji wymaga superwizji i stawia warunek rozwoju własnego i samoszkolenia się coacha.

Coaching różni się tym od psychoterapii, że to klient coacha określa cel swojej pracy i definiuje efekty, po których oceni, czy proces pracy można już zakończyćc ${ }^{34}$. W doradztwie filozoficznym kwestia ta pozostaje otwarta. Na ile filozof będzie miał wpływ na ustalenie celów i efektów pracy? Im większy będzie wpływ filozofa na określenie ram pracy, tym bardziej proces ten zbliżał będzie się do dyrektywnej terapii, a oddalał od coachingu.

Sam coaching różni się w zależności od danych szkól, lecz możliwym jest wyznaczenie pewnych głównych, lecz nie wszystkich jego odmian ${ }^{35}$ : 1) coaching biznesowy (organizacyjny, biznesowy, kariery; 2) executive coaching - coaching wykonawczy (kierowany do kadry managerskiej najwyższego szczebla); 3) coaching życiowy (life

34 Ł. Marciniak, art. cyt.

35 A. Scoular, M. Nosorowska, Coaching biznesowy, Gdańsk 2014; Ł. Marciniak, art. cyt. 
coaching); 4) coaching sportowy; 5) coaching zdrowia; 6) coaching edukacyjny.

Jeśli chodzi o zakres pracy i profil potencjalnego klienta, coaching wydaje się najbliższy doradztwu filozoficznemu. Doradca filozoficzny nie ma jednak ograniczenia czasowego pracy z klientem. O ile terapeuta może pracować $\mathrm{z}$ klientem przez lata, o tyle coach pracuje raczej w krótkim czasie, zamykając swoją pracę raczej w kilku do kilkunastu sesjach. Doradztwo filozoficzne można więc określić jako dłuższą formę pracy z klientem w zależności od podejścia, według jakiego pracuje filozof. Coach z założenia nie musi mieć wiedzy specjalistycznej z danej dziedziny i doradca filozoficzny także. Różnica jednak może tkwić w poziomie wiedzy i wpływie na proces pracy doradcy filozoficznego. Jeśli zakładamy, że filozof pracuje według pewnego planu, to ingeruje w proces pracy klienta. Staje się raczej przewodnikiem po nieznanych klientowi obszarach, co odróżnia go wyraźnie od roli coacha. $Z$ założenia więc jego pozycja wzrasta. Kolejną kwestią jest dość swobodne podejście do superwizji w doradztwie filozoficznym, co odróżnia ten rodzaj pracy od coachingu. Jest to zapewne kwestia tego, że doradztwo udzielane przez filozofów jest zjawiskiem dość młodym i wraz ze wzrostem popularności tego typu pracy uformuje się jakiś rodzaj nadzoru i wsparcia koleżeńskiego. W obecnym kształcie doradztwa filozoficznego takiego wymogu czy możliwości jednak nie ma.

\section{PODSUMOWANIE}

Zarówno psychoterapia, poradnictwo psychologiczne, coaching, jak i poradnictwo filozoficzne mogą być ciekawymi formami pracy i wspierania jednostki. Nie mogą być to jednak dziedziny, w których panuje bałagan uniemożliwiający dokonanie świadomego wyboru klientowi / pacjentowi. Przedstawiciele pokrewnych dziedzin oraz osoby będące doradcami filozoficznymi powinny mieć jasność co do tego, jaki jest zakres ich pracy i kompetencji. Ważnymi kwestiami 
są równiez: czas trwania kształcenia, superwizja pracy własnej, długość pracy z klientem, przeznaczenie oddziaływania, farmakoterapia towarzysząca pracy; kto ma wpływ na kierunek pracy; dyrektywność. Tabela 1 porównuje ze sobą opisywane wcześniej formy pracy z klientami.

Tab. 1. Porównanie psychoterapii, poradnictwa psychologicznego, coachingu i doradztwa filozoficznego

\begin{tabular}{|c|c|c|c|c|}
\hline & Psychoterapia & $\begin{array}{l}\text { Poradnictwo } \\
\text { psychologiczne / } \\
\text { interwencja }\end{array}$ & Coaching & $\begin{array}{l}\text { Doradztwo } \\
\text { filozoficzne }\end{array}$ \\
\hline Kto może zostać? & $\begin{array}{l}\text { Wymagane: } \\
\text { studia wyższe } \\
\text { i zazwyczaj kil- } \\
\text { kuletnia szkoła } \\
\text { psychoterapii }\end{array}$ & $\begin{array}{l}\text { Wymagane: } \\
\text { pięciolet- } \\
\text { nie studia } \\
\text { magisterskie }\end{array}$ & $\begin{array}{l}\text { Zalecany: } \\
\text { akredyto- } \\
\text { wany kurs }\end{array}$ & $\begin{array}{l}\text { Sugerowane: } \\
\text { ukończenie } \\
\text { studiów } \\
\text { doradztwa } \\
\text { filozoficznego }\end{array}$ \\
\hline $\begin{array}{l}\text { Czas trwania } \\
\text { kształcenia }\end{array}$ & 4-5 lat & 5 lat & $\begin{array}{l}\text { Zależnie od } \\
\text { kursu }\end{array}$ & $3,5-5$ lat \\
\hline $\begin{array}{l}\text { Superwizja pracy } \\
\text { własnej }\end{array}$ & Tak, wymagana & $\begin{array}{l}\text { Tak, } \\
\text { niewymagana }\end{array}$ & $\begin{array}{l}\text { Tak, } \\
\text { niewymagana }\end{array}$ & $\begin{array}{l}\text { Rekomendo- } \\
\text { wana }\end{array}$ \\
\hline $\begin{array}{l}\text { Długość pracy } \\
\text { z klientem } \\
\text { (orientacyjnie) }\end{array}$ & $2-5$ lat & $\begin{array}{l}\text { Nieogra- } \\
\text { niczona, } \\
\text { zazwyczaj od } 1 \\
\text { do kilkunastu } \\
\text { spotkań }\end{array}$ & 6-10 spotkań & $\begin{array}{l}\text { W zależności } \\
\text { od ustaleń }\end{array}$ \\
\hline $\begin{array}{l}\text { Wymagania co do } \\
\text { zdrowia klienta: }\end{array}$ & $\begin{array}{l}\text { Osoby zdrowe } \\
\text { i chore } \\
\text { psychicznie }\end{array}$ & $\begin{array}{l}\text { Osoby zdrowe, } \\
\text { w kryzy- } \\
\text { sie, chore } \\
\text { psychicznie }\end{array}$ & $\begin{array}{l}\text { Osoby } \\
\text { zdrowe } \\
\text { psychicznie }\end{array}$ & $\begin{array}{l}\text { Osoby } \\
\text { zdrowe } \\
\text { psychicznie }\end{array}$ \\
\hline $\begin{array}{l}\text { Farmakoterapia } \\
\text { towarzysząca pracy }\end{array}$ & $\begin{array}{l}\text { Tak, wg zaleceń } \\
\text { psychiatry }\end{array}$ & $\begin{array}{l}\text { Tak, wg zale- } \\
\text { ceń psychiatry }\end{array}$ & $\begin{array}{l}\text { Nie lub po } \\
\text { ustaleniu } \\
\text { z lekarzem }\end{array}$ & $\begin{array}{l}\text { Nie lub po } \\
\text { ustaleniu } \\
\text { z lekarzem }\end{array}$ \\
\hline $\begin{array}{l}\text { Kto ma wpływ na } \\
\text { kierunek pracy }\end{array}$ & $\begin{array}{l}\text { Psychoterapeuta } \\
\text { i klient }\end{array}$ & $\begin{array}{l}\text { Psycholog, } \\
\text { interwent }\end{array}$ & Klient & $\begin{array}{l}\text { Doradca } \\
\text { filozoficzny } \\
\text { i klient }\end{array}$ \\
\hline Dyrektywność & $\begin{array}{l}\text { Zależnie od } \\
\text { szkoły }\end{array}$ & Tak & Nie & Tak/ Nie \\
\hline
\end{tabular}


Wobec tego osoby, które będą wykonywały zawód (jeśli będzie to formalnie zawodem) doradcy filozoficznego powinny zadbać o kilka kwestii. Doradcą powinna być osoba, która ma kompetencje do tego rodzaju pracy, np. potwierdzone dyplomem ukończenia studiów wyższych z zakresu filozofii lub doradztwa filozoficznego. Doradca filozoficzny tak jak coach, psychoterapeuta i psycholog powinien otwarcie informować klienta o metodzie, jaką pracuje. Klient powinien mieć informacje umożliwiające określenie kompetencji doradcy filozoficznego, jego doświadczenia i rekomendacji zawodowych tak, aby świadomie podjąć decyzję o rozpoczęciu współpracy. Doradca filozoficzny powinien podlegać pewnym formom nadzoru, superwizji określonych przez środowisko filozofów. Klient powinien być uczciwie przekierowywany w chwili wykrycia przez doradcę, że osoba powinna podlegać leczeniu psychiatrycznemu lub diagnozie. Klient doradcy nie powinien znajdować się w procesie leczenia, chyba że praca $z$ filozofem jest $w$ jakimś sensie uzupełnieniem terapii ustalonym z góry. Doradca filozoficzny powinien pracować w oparciu o kodeks etyczny, z którym może zapoznać się klient. Doradca filozoficzny powinien jasno określić ramy swojego działania i formy pracy z klientem. Wciąż pozostaje kilka pytań bez odpowiedzi, takich jak np. to, czy doradca filozoficzny powinien posiadać ubezpieczenie zawodowe. Ważna jest również kwestia odpłatności za poradnictwo filozoficzne.

Klientem doradcy filozoficznego powinna być osoba zdrowa psychicznie lub bez widocznych objawów chorobowych (w momencie rozpoczęcia pracy). Jeśli jest osobą, która miała epizody leczenia psychiatrycznego, powinna być po zakończonym procesie terapii i w stabilnej reemisji objawów choroby. Klient powinien też móc świadomie sam podjąć decyzję o podjęciu pracy z filozofem. Wyzwaniem dla środowiska filozofów jest stworzenie ram zawodu doradcy filozoficznego. Praca doradcy filozoficznego bez ustalonych ram pracy jest niejasna. Ważne jest dookreślenie formy superwizji - sama konieczność raczej powinna być standardem. Ważne jest uściślenie 
form, procedur, definicji doradztwa filozoficznego na tyle, na ile jest to możliwe w ramach danego podejścia. Stworzenie organizacji skupiających, certyfikujących tego typu doradców mogłoby podnieść świadomość przyszłych klientów i pomogłoby nakreślić model pracy i standardy jakości. Kluczowym dla rozwoju tej nowej formy pracy z ludźmi jest zwiększenie świadomości społecznej tego, czym jest doradztwo filozoficzne i w jaki sposób odróżnia się od innych metod pracy z klientem. Umiejętność radzenia sobie z nieetycznymi praktykami, które towarzyszą także psychologom, psychoterapeutom i coachom. Pozostaje niestety także problem podszywania się różnego rodzaju hochsztaplerów pod doradców filozoficznych. Nie jest to problem jedynie filozofów, a wszystkich zawodów zaufania społecznego. Doradztwo filozoficzne może być bardzo ciekawą i wnoszącą powiew świeżości dziedziną rozwoju osobistego, jeśli nie zmarnuje swojej szansy i dookreśli ramy tego „kim jest?”, co „robi” a czego „nie robi" doradca filozoficzny.

\section{BIBLIOGRAFIA}

Adler A., Sens życia, tłum. z niem. M. Kreczowska, Państwowe Wydawnictwo Naukowe, Warszawa 1986.

Albee G.W., Prologue: A model for classifying prevention programs, Readings in Primary Prevention of Psychopathology: Basic Concepts (1984), 228-245.

Antonovsky A., The salutogenic model as a theory to guide health promotion, Health Promotion International 11(1996)1, 11-18.

Aronson E., Wilson T.D., Akert R.M., Psychologia spoteczna: serce i umyst, tłum. z ang. A. Bezwińska i in., Zysk i S-ka, Poznań 1997.

Barbaro de B., Tezy o psychoterapii w Polsce, Psychoterapia 1(2013), 5-14

Beck A.T., Chodkiewicz J., Witkowska J., Terapia poznawcza uzależnień, Wydawnictwo Uniwersytetu Jagiellońskiego, Kraków 2007.

Caplan G.E., Prevention of mental disorders in children: Initial explorations, Basic Books, New York 1961.

Carson R.C., Butcher J.N., Mineka S., Psychologia zaburzen, tłum. z ang. W. Dietrich i in., Gdańskie Wydawnictwo Psychologiczne, Gdańsk 2003. 
Czabała J., Czynniki leczqce w psychoterapii, Wydawnictwo Naukowe PWN, Warszawa 2006.

Czabała J., Sęk H., Pomoc psychologiczna, w: Psychologia. Podręcznik akademicki, red. J. Strelau, Gdańskie Wydawnictwo Psychologiczne, Gdańsk 2000.

Czarkowska L.D., Profesjonalizm i proces profesjonalizacji w coachingu, Coaching Review 1(2010), 1-17.

Freud A., The ego and the mechanisms of defence, Karnac Books, London 1992.

Grzesiuk L., Psychoterapia teoria, cz. 1, Eneteia Wydawnictwo Psychologii i Kultury, Warszawa 2005.

Grzesiuk L., Tryjarska B., Jak pomagać sobie, rodzinie i innym, Wydawnictwo Naukowe PWN, Warszawa 1995.

ICD-10: International statistical classification of diseases and related health problems, World Health Organization, Geneva 2011.

Knapp S., Tjeltveit A.C., A Review and Critical Analysis of Philosophical Counseling, Professional Psychology: Research and Practice 36(2005)5, 558-565.

Louw D., Defining Philosophical Counselling: An Overview., South African Journal of Philosophy 32(2013)1, 60-70.

Marciniak Ł., Pojęcie i odmiany coachingu, w: Coaching. Teoria, praktyka, studia przypadków, red. M. Sidor-Rządkowska, Wolters Kluwer Polska, Kraków 2009, 32-36.

Minuchin P., Families and individual development: Provocations from the field of family therapy, Child Development 56(1985), 289-302.

Obuchowski K., Człowiek intencjonalny, czyli o tym, jak byćsobą, Dom Wydawniczy Rebis, Poznań 2000.

Polskie Towarzystwo Psychologiczne, Projekt ustawy z kwietnia 1996 roku o zawodzie psychologa i samorządzie zawodowym psychologów, Warszawa 1996.

Radochoński M., Psychoterapia rodzinna w ujęciu systemowym, Wydawnictwo Wyższej Szkoły Pedagogicznej, Warszawa 1984.

Roberts A.R., An overview of crisis theory and crisis intervention, Oxford University Press, New York 2000.

Rogers C.R., The process equation of psychotherapy, American Journal of Psychotherapy $15(1961), 27-45$.

Satir V., Conjoint family therapy, Science and Behavior Books, Palo Alto 1983.

Scoular A., Nosorowska M., Coaching biznesowy, Gdańskie Wydawnictwo Psychologiczne, Gdańsk 2014.

Słońska Z., Ewolucja modeli edukacji zdrowotnej, Kultura Fizyczna (1994)5-6, 16-21. Šulavíková B., Questions for philosophical counselling, Human Affairs 22(2012)2, 131-141. 
Whitmore J., Coaching for performance: growing human potential and purpose: the principles and practice of coaching and leadership, Nicholas Brealey Publishing, London 2010.

Yalom I.D., Existential psychotherapy, Basic Books, New York 1980.

Yalom I.D., Leszcz M., Andruszko R., Psychoterapia grupowa: teoria i praktyka, Wydawnictwo Uniwersytetu Jagiellońskiego, Kraków 2006.

Yalom I.D., Tanalska-Dulęba A., Psychoterapia egzystencjalna, Instytut Psychologii Zdrowia - Polskie Towarzystwo Psychologiczne, Warszawa 2008.

\title{
A CRITICAL COMPARISON OF PHILOSOPHICAL COUNSELING AND PSYCHOTHERAPY, COUNSELING AND COACHING FROM A PSYCHOLOGIST'S STANDPOINT
}

\begin{abstract}
This article is an attempt to define philosophical counseling and compare it to professional psychological help, psychotherapy and coaching. In the first part, the author describes different types of psychological help and compares them to philosophical counseling. The next section focuses on psychotherapeutic approaches, which are also compared with philosophical counseling. Lastly, the author describes coaching, outlines commonalities with the other approaches and offers advice to the philosopher. The general conclusions of this comparative analysis can be summarized as follows. Philosophical counseling is a young field in Poland. We need to clarify its conceptual framework and scope by clearly demarcating the activities of philosophical counselors, psychologists, psychotherapists and coaches. It is important to emphasize that philosophical counseling is an approach to working with mentally healthy people, and that it cannot replace individual or group psychotherapy and professional psychological help. It is, however, an interesting approach similar to coaching. Philosophical coaching has great potential to become a successful practice for promoting the personal development of healthy people.
\end{abstract}

Keywords: philosophical counseling, philosophical coaching, professional psychological help, psychotherapy, coaching

PRZEMYSŁaW ZDYBEK

pzdybek@uni.opole.pl

Uniwersytet Opolski, Instytut Psychologii

Plac Staszica 1, 45-052 Opole

DOI: $10.21697 /$ spch.2018.54.3.13 